San Jose State University

SJSU ScholarWorks

Faculty Publications

$1-1-2007$

\title{
Tackling the Monday Morning Quarterback: Applications of Hindsight Bias in Decision-Making Settings
}

\author{
T. A. Louie \\ San Jose State University \\ Mahesh N. Rajan \\ San Jose State University, mahesh.rajan@sjsu.edu \\ Robert E. Sibley \\ San Jose State University, robert.sibley@sjsu.edu
}

Follow this and additional works at: https://scholarworks.sjsu.edu/mktds_pub

Part of the Business Commons

\section{Recommended Citation}

T. A. Louie, Mahesh N. Rajan, and Robert E. Sibley. "Tackling the Monday Morning Quarterback: Applications of Hindsight Bias in Decision-Making Settings" Social Cognition (2007): 32-47. https://doi.org/10.1521/soco.2007.25.1.32

This Article is brought to you for free and open access by SJSU ScholarWorks. It has been accepted for inclusion in Faculty Publications by an authorized administrator of SJSU ScholarWorks. For more information, please contact scholarworks@sjsu.edu. 


\section{TACKLING THE MONDAY-MORNING QUARTERBACK: APPLICATIONS OF HINDSIGHT BIAS IN DECISION-MAKING SETTINGS}

Therese A. Louie, Mahesh N. Rajan, and Robert E. Sibley San Jose State University

Extant research has focused largely on what causes hindsight distortion. In contrast, this work examines applied aspects related to the bias in decision-making environments. A conceptual framework is provided and recent real-world examples are presented to outline how decision makers-and those who observe them-show hindsight effects. Then, both negative and positive consequences of the bias are outlined. Strategies are presented to reduce negative effects that occur when decision makers show hindsight distortion. Finally, because it is often not possible to avoid or to correct others' hindsight-tainted evaluations, suggestions for coping with the bias are discussed.

Human progress depends upon learning from the past. Perhaps that is why hindsight bias-wherein outcomes seem more obvious in hindsight than they did in foresight (Fischhoff, 1975) - -has received so much attention from academic researchers (for reviews see Christensen-Szalanski \& Willham, 1991, and Guilbault, Bryant, Brockway, \& Posavac, 2004). Although the bias can be affected by personality differences (Musch, 2003) and cultural influences (Pohl, Bender, \& Lachmann, 2002), it is prevalent in a wide variety of

Therese A. Louie, College of Business; Mahesh N. Rajan, College of Business; Robert E. Sibley, College of Business.

We thank Annie Siu, Ione Burford, Crystal Sioteco, Tiffany Phan, Jochen Musch, Hartmut Blank and anonymous reviewers for their help.

Address correspondence to Therese A. Louie, College of Business, San Jose State University, One Washington Square, San Jose, California, 95192; E-mail: tlprofsj@cob.sjsu.edu. 
settings wherein outcome information is known (for a review see Hawkins \& Hastie, 1990).

This article provides an overview of applied aspects related to hindsight distortion in decision-making environments. First, findings from academic research are presented, and are illustrated by scenarios from real-life settings. Then, applied examples provide insights into the costs, as well as the benefits, of the bias. Next, the means by which to avoid negative consequences of the bias are discussed. Finally, because it is not always possible to avoid hindsight effects, strategies for coping with them are outlined.

\section{RESEARCH ON HINDSIGHT BIAS IN DECISION MAKING SETTINGS}

\section{HINDSIGHT BIAS WHEN OBSERVING OTHERS' DECISION OUTCOMES}

Research Findings. The ABI/INFORM and PsychInfo databases were used to find experimental research that focused on hindsight bias for event outcomes. The list was then narrowed by requesting articles that contained the words "decision-making" in their abstracts or key words.

The research stream is split generally into studies that focused upon individuals observing others' decisions, and decision makers evaluating their own choices. When individuals observe another's decision, they tend to show hindsight bias both when outcomes are unfavorable and favorable. For example, Bukszar and Connolly (1988) asked three sets of participants to read about a managerial decision that took place in a company. The first group was given no information about the outcome and was asked to make judgments regarding whether or not the result of the decision would be successful. A second set of participants was provided with information that the decision outcome was unfavorable, and a third group learned that the outcome was favorable. The last two groups of participants were then asked to make "postdictions," or judgments about what they would have predicted would happen had they not seen outcome information. When the researchers compared the postdiction judgments with the prediction judgments of the first group of participants, they found that the outcome was more obvious in hindsight than in foresight, regardless of the direction of the decision result.

Although some researchers have found hindsight effects primarily for others' unfavorable decision outcomes (Hastie, Schkade, \& Payne, 1999; Lowe \& Reckers, 1994; Menec \& Weiner, 2000), many studies have replicated Bukszar and Connolly's (1988) pattern of hindsight findings for both unfavorable and favorable outcomes (Connolly \& Bukszar, 1990; Louie, 2005; Schkade \& Kilbourne, 1991; Sligo \& Stirton, 1998). In addition, the bias has been displayed in a wide range of judgment milieus, including those involving healthcare concerns (e.g., Borum, Otto, \& Golding, 1993), legal issues (e.g., Hastie et al., 1999), consumption experiences (Pohl, Schwarz, 
Sczesny, \& Stahlberg, 2003), and political results (Blank, Fischer, \& Erdfelder, 2003).

Real-World Examples. The Enron Corporation story suggests that in real-world settings-similar to what was found in theoretical research-observers show hindsight bias for others' unfavorable and favorable decision outcomes. Up until the early 2000s, Enron was extremely powerful, having been voted multiple times as the most innovative company in the U.S. (Ellis, 2002). Hindsight bias for the company's success (e.g., "I knew they would be profitable because the company is so innovative") fueled Enron's dynamic image. Many analysts decided to invest clients' money in Enron stock. Those who remained unconvinced by the new economy hype were deemed as old-fashioned and as missing the opportunity for inevitable success (Shell \& Krantz, 2001). In the early 2000s, Enron was ranked seventh on the Fortune 500 list (Fortune Five Hundred Largest U.S. Corporations, 2001).

Yet, when Enron's CEO announced a negative earnings adjustment of $\$ 1.2$ billion in 2001, the public switched from admiring the company's management practices to holding them in contempt. Soon, the Enron failure became the biggest bankruptcy in U.S. history. Hindsight bias for the now unfavorable outcome information prompted individuals to scorn financial advisors for not anticipating what, in retrospect, seemed like the company's inevitable failure. As pointed out by a director of research at Off Wall Street, a consulting firm, "Wall Street is a fashion show and Enron was fashionable . .. the analysts were not analyzing, they were believing. They overlooked signs that there might be trouble because they were personally enthused" (McNulty, 2001, p. 1).

\section{HINDSIGHT BIAS FOR DECISION MAKERS' OUTCOMES}

Research Findings. In addition to focusing on observers' reactions to others' choices, researchers have examined how individuals show hindsight effects for their own decision outcomes. Unlike mere observers of others' actions, decision makers have something at stake in the results of their choices. In more personally relevant settings, individuals show self-serving tendencies wherein they accept credit for favorable outcomes, and deny blame for unfavorable outcomes (for a review see Taylor \& Brown, 1988). Accordingly, Louie (1999) found that decision makers show hindsight bias when their outcomes are favorable (e.g., "I knew I would succeed") but not when the results are unfavorable (e.g., "My idea should have worked"). This asymmetric hindsight result has been replicated in other studies examining decision outcome foreseeability (Louie, Curren, \& Harich, 2000; Mark, Boburka, Eyssell, Cohen, \& Mellor, 2003).

Additional evidence that individuals show hindsight effects only when outcomes agree with their viewpoints comes from studies wherein participants observe, yet also have prior established opinions about, others' decision making (e.g., Robbennolt \& Sobus, 1997). In a field study, Holzl, 
Kirchler, and Rodler (2002) found that individuals showed hindsight bias for another's decision when the outcome agreed with their prior attitudes. In contrast, observers did not show the bias for decision outcomes that were contrary to their previous views.

Real-World Example for Unfavorable Decision Outcomes. Congruent with research findings, individuals in real-world settings do not show hindsight bias when outcomes are contrary to their decision making. In 2002, a 19-year-old named Kacey elected to have breast augmentation surgery, putting the $\$ 4,500$ cost on a payment plan. Initially, she enjoyed her new appearance. However, within a couple of months, she started developing health problems such that simple chores like brushing her hair became difficult. When checking online for information she was horrified to discover that her experiences paralleled those of other women who had also had augmentation surgery. Not only did she not show hindsight bias, she incredulously wondered, "Why hadn't anyone said anything?" (Kula, 2004, p. 15).

Eventually, she had the implants removed. Her healing process included 60 medical appointments in a year and weekly IV treatments to reduce the pain. Her experiences were profiled publicly to prompt teens to consider her experience before having augmentation surgery.

Note that although Kacey did not have hindsight distortion for her unfavorable decision outcome, others observing women in her position have shown the bias. Those uninvolved in the decision have been unsympathetic, noting that women who chose to have augmentation should have known about the high risks (Food and Drug Administration Medical Devices Advisory Committee, 2000). In actuality, informed consent for the surgery is not mandatory (Zuckerman, 2001). Hence, these examples are congruous with the results of laboratory findings that the pattern of hindsight bias differs with the perspective of the individual making hindsight estimates. When outcomes are unfavorable, observers show hindsight bias but decision makers do not.

Real-World Example for Favorable Decision Outcomes. It is a bit tricky to prove the existence of the bias for decision makers' favorable outcomes. Because individuals tend to be optimistic about their own futures (Taylor \& Brown, 1988), they may indeed have truly foreseen their success. Hence, this example starts with an unfavorable occurrence, but backtracks to show that the outcome likely occurred due to hindsight effects following favorable results.

In the 2004 Olympics, the American women's $4 \times 100$-meter relay team ran an exceptional qualifying race. Some observers felt that the team then developed hindsight bias and became unduly self-assured. One team member suggested that viewers who planned to watch the final should not blink or, "you'll miss the race" (Killion, 2004, p. 1). The team had enormous talent (the four women were among the top six female sprinters in the world) and had reasons to believe, based upon past experiences, that success was likely. However, one downside was that they previously had run in only one meet 
together. During the final there were problems with the baton exchange, which led to their disqualification. A "we knew we were great and will continue to win" attitude reflects hindsight effects that may have led to carelessness in the race.

In sum, research findings indicate that hindsight bias is prevalent for both unfavorable and favorable outcomes when individuals are uninvolved observers of the decision making. However, the effects are different when individuals themselves are the decision makers, or when they have strong prior attitudes about the decision in question. In those cases, they show the bias for outcomes that in their view are favorable, but do not show the bias for those that are unfavorable. Real-world examples suggest that the same pattern of bias seen in experimental studies emerges in true decision-making settings. In addition, past events provide a backdrop from which to discuss consequences of the bias.

\section{NEGATIVE AND POSITIVE CONSEQUENCES OF HINDSIGHT EFFECTS}

\section{NEGATIVE CONSEQUENCES}

Bottom-Line Losses. As noted in Table 1, there are both negative and positive consequences of hindsight effects.

Regarding the former, real-life scenarios underscore that hindsight bias can have disastrous consequences for decision makers and for those who depend upon them. For example, some analysts would claim that the Nobel laureates and other prominent economists who formed the hedge fund Long-Term Capital Management suffered from the same hindsight-based hubris as that shown by Enron executives. Confident from their past successes, the former continued investing and borrowing heavily even when they were warned that collapsing economies around the world made their actions extremely risky (Glassman, 1998). As a result, during the stock market turmoil of 1998, Long-Term Capital Management lost $90 \%$ of its investors' money. The negative repercussions were heightened further by bank managers who admired the company partners, and who sought to emulate their actions by making similar dealings for their own clients. The bottom-line consequences of hindsight-based decision making can be far-reaching.

Reduced Rational Thinking. In addition to bottom-line consequences, hindsight effects can encourage strong emotions (Stewart, 2003) that reduce rational thinking and actions. When 2005's Hurricane Katrina proved disastrous and fatal for some residents of New Orleans, the public angrily criticized the chief of the Federal Emergency Management Agency (FEMA) for being slow to make lifesaving decisions. One journalist, noting the strong tendency to place blame and to show retroactive biases in the aftermath of disaster, wrote an article titled, "Hindsight Elevates the Droves Who Saw 
Katrina Coming" (Kinsley, 2005). Yet, the drive to find a scapegoat can reduce rational thinking that might be better placed in dealing with the crisis.

Impeded Learning from Experience. Hindsight bias can obscure learning from past decision-making mistakes. In 2003, the crew of the American space shuttle Columbia was doomed as their vehicle fell apart upon reentering the Earth's atmosphere (Surowiecki, 2004). The wreckage was caused by a piece of foam that broke off during lift-off and smashed into the shuttle's left wing. Prior to the reentry attempt, a NASA team decided against studying the potential damaging effect of the foam. Had the research instead been conducted, it might have prevented the fatal disaster.

It would be easy to show hindsight bias for the team's decision (e.g., "They should have known to investigate"). Yet, experts note that doing so would be unwise. It would discourage examining larger institutional problems at NASA that may have caused the tragedy. According to some analysts, there is indeed evidence of not learning from the past; many of the troubles resulting in Columbia's tragedy were prevalent when the Challenger shuttle exploded over a decade earlier (Surowiecki, 2004). A minority report produced by members of an oversight committee monitoring NASA noted that, "It is difficult to be objective based on hindsight, but it appears that lessons that should have been learned have not been" (NASA Accused of Breaking Safety Rules in Rush to Launch Discovery, 2005, p. 1). Hence, simplifying the causes of bad outcomes as inevitable and as based upon single decisions obscures larger lessons that could be used to avoid future disasters.

Reduced Sensitivity to Victims and Discouraged Preventive Actions. Another negative consequence of hindsight effects occurs when those who face unfavorable decision outcomes are not taken seriously. That result can be demoralizing, and can hinder the implementation of corrective actions. As noted above, some individuals feel that women who have health problems resulting from breast augmentation surgery should have known about the risks involved in their decisions. Such a conclusion belittles the experiences of those suffering ill effects. Combined with the finding that hindsight effects increase over time to real-world events (Bryant \& Brockway, 1997), the lack of empathy for unfavorable outcomes also allows the industry to continue without providing more careful warnings.

\section{POSITIVE CONSEQUENCES}

Increased Confidence and Performance. Hindsight bias has been linked to exaggerated levels of confidence (e.g., Bukszar \& Connolly, 1988). Although biases are often assumed to be negative, if the confidence produced by hindsight distortion for past success is contained, then it can result in favorable effects. Research findings on self-serving biases (Taylor \& Brown, 1988) suggest that individuals who have positive self-views have increased motivation, persistence, and performance compared to individuals who have less 
TABLE 1. Applied Aspects of Decision Makers' Hindsight Bias

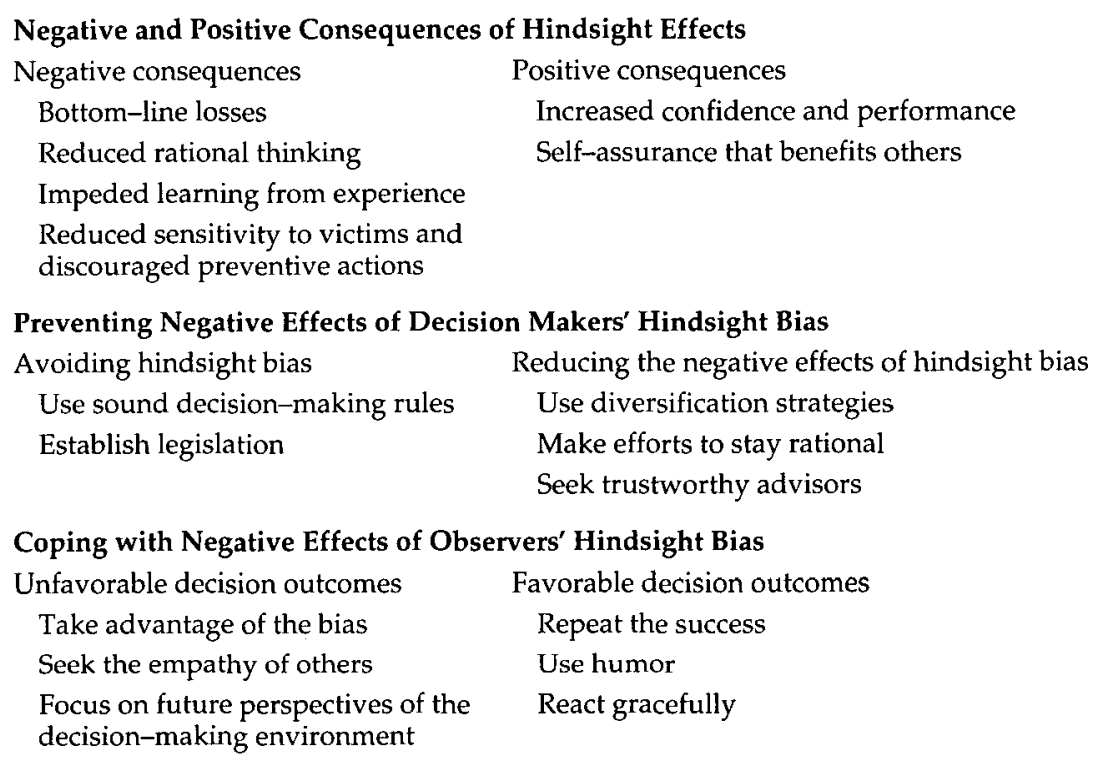

positive self-views. These are traits that benefit decision makers, as well as others with whom their skills are shared.

An individual who may be benefiting from confidence-encouraging hindsight bias is Danica Patrick. In 2005, she broke into what has often been considered "a man's world," that of Indy Car racing. Her accomplishments included two "pole positions" (fastest qualifier for a race), and being named the 2005 Rookie of the Year in Indy Car racing. She appeared on numerous television shows, and on the cover of Sports Illustrated (Media, n.d.). When asked if she had foreseen all of the wonderful things that had occurred to date in her career, Patrick responded that she had. "I've been racing since I was 10 and wanted to be in the Indy 500 since I was 12 ," she said. "I just had to have faith that it was going to happen" (Shaffer \& Stilley, 2005, p. 2).

Had she truly foreseen such favorable outcomes in her race performance, and in the public reaction to her? Or was she demonstrating hindsight bias and confidence based upon past accomplishments? Regardless, provided that she does not make overly risky decisions, any hindsight bias in this case may be more beneficial than harmful. In interviews, Patrick noted that without such a belief in oneself, favorable outcomes will not happen (Burnett, 2005). Her confidence has helped her to pursue her dream, and may encourage others from groups not traditionally associated with racing to pursue the sport.

Self-Assurance That Benefits Others. Somewhat counter-intuitively, even stories of tragedies can illustrate past positive effects of hindsight bias. In his 
book, Into Thin Air, Jon Krakauer (1997) provided a personal account of his experience during an ill-fated Mount Everest climb. In that expedition, several climbers who reached the summit lost their lives. Among those who died were experienced professional guides. To explain how the tragedy occurred, Krakauer cited uncontrollable factors, such as bad weather. He also noted that possible errors in judgment-such as the decision not to descend at the predetermined safety turn-around time-may have been based upon hubris gained from leading previous expeditions.

Yet, if it is true that hindsight-based overconfidence contributed to the guides' deaths, then it is also true that their earlier faith in their abilities previously benefited them and numerous others. One individual, in addition to leading expeditions, was a successful helicopter-skiing guide, spent summers working for geologists doing research in Antarctica, and helped to run a medical clinic created to treat altitude-related illnesses. The guides' self-assured decision making allowed them to share their skills with clients and associates who might otherwise have missed the adventures.

Success is a combination of talent, hard work, good timing and, perhaps, the hindsight bias of dreams. As long as confidence produced by the bias is kept in perspective, it can be beneficial. This brings to light the question of how decision makers can prevent overconfidence, and other deleterious effects resulting from the bias.

Some might argue that the preventive measures that we are about to discuss actually target poor decision-making behavior rather than negative consequences of hindsight bias. We contend, though, that the conclusion that these are poor decisions results from a post hoc analysis of the situation after the outcome is known. This is, by definition, a hindsight phenomenon. Additionally, hindsight bias and poor decision making are iterative such that one can affect the other. Therefore, it is worthwhile to discuss preventive measures devoted to ameliorating the bias and its effects on decision making.

\section{PREVENTING NEGATIVE EFFECTS OF DECISION MAKERS' HINDSIGHT BIAS}

\section{AVOIDING HINDSIGHT BIAS}

Use Sound Decision Making Rules. One way for decision makers to avoid hindsight effects is to stick with rules that have withstood the test of time. In 2005, Forbes magazine ranked Warren Buffett as the second-richest man in the world (Kroll \& Goldman, 2005). One of the very few to accomplish this feat solely by making wise investments in other companies, Buffett has long attributed his success to consistent principles that, in turn, help him avoid retrospective biases. He invests in companies that (a) he knows something about, (b) are undervalued or out of favor, (c) have low overhead costs, (d) exhibit high growth potential, (e) possess strong market share, (f) exhibit 
low price--to-earnings ratios, and $(\mathrm{g})$ have strong management in place (Hagstrom, 2004).

Note that these decision-making principles have allowed Buffett to avoid the cognitive biases brought about by mob psychology on Wall Street. He could easily have fallen prey to hindsight bias. When he did not jump at opportunities offered by the dot.com boom, some analysts publicly claimed that he was out of touch (cf. Shell \& Krantz, 2001). Yet, he avoided the subsequent dot.com bust because the investments did not meet his principles. By sticking with what he knew, he was less prone to develop hindsight bias, and had the strength to resist influence from others' retrospectively biased conclusions.

Establish Legislation. A second way to prevent decision makers' hindsight effects is to have legislation that discourages actions that could be potentially harmful to the citizenry and, thereby, could prompt the bias (e.g., "I told you so" effects). For example, after the Enron fiasco, there were cries to make accounting firms more responsible. The United States Congress passed the Sarbanes-Oxley Act, which developed more rigorous checks and balances, and stronger punishments to those who overconfidently flout the rules (e.g., Summary of Sarbanes-Oxley Act of 2002, 2005). Those efforts should help to curb hindsight bias and the irrational decision making that it can produce. Also, referring back to the example about breast augmentation surgery, some consumer advocates feel that such risk-oriented products should be sold only with regulations that formally warn patients of potential dangers (Zuckerman, 2001). With official warnings in place, perhaps fewer women would elect to have the surgery, and the number of occurrences of the bias for those unfavorable outcomes would be reduced.

\section{REDUCING THE NEGATIVE EFFECTS OF HINDSIGHT BIAS}

Use Diversification Strategies. When it is difficult for decision makers to avoid showing hindsight distortion, efforts can be made to reduce its deleterious effects. For example, individuals can decrease the negative consequences related to unfavorable decision outcomes by using a diversification strategy. Referring back to the Enron example, many individuals invested in the company because they "knew" that the success would continue. When the company failed, those who stuck with the basic investment principle to diversify were not as hard hit as those who lost everything by focusing narrowly on Enron. In short, unfavorable consequences can be minimized when individuals are not overly vulnerable to decisions that might be tainted by hindsight effects.

Make Efforts to Stay Rational. Another way to avoid consequences of hindsight effects comes from Daniel Kahneman, who won the 2002 Nobel Prize for work on the psychology of economic decision making. As noted earlier, it is unwise to get emotional about outcomes because such reactions interfere with rational thinking. How does this world-renowned expert keep his 
feelings in check? He removes himself from the information that gives rise to the emotions. Regarding investment decision outcomes, he does not take every opportunity to check his portfolio, stating, "I'd be swinging from good moods to bad all the time if I did" (Stewart, 2003, p. 83). Of course, those who disregard investment-related news run the risk of remaining too long in losing investments. In any case, staying rational- - whether or not it includes resisting short-run information-may reduce negative hindsight effects.

Seek Trustworthy Advisors. An additional way for decision makers to avoid irrational choices tainted by hindsight is to obtain advice from external parties that do not have a personal stake in the decision making. Successful individuals know the value of seeking independent, trustworthy opinions. When musician Prince was inducted into the Rock and Roll Hall of Fame in 2004, he advised younger musicians, "A real friend and mentor is not on your payroll" (Bauder, 2004, p. 1). Outside auditors can keep decision makers grounded in reality.

Although decision makers can make efforts to keep their own hindsight bias in check, sometimes it is not possible to avoid negative consequences that occur when observers show the bias. Hence, methods to cope with such situations are now presented.

\section{COPING WITH NEGATIVE EFFECTS OF OBSERVERS' HINDSIGHT BIAS}

\section{UNFAVORABLE DECISION OUTCOMES}

Take Advantage of the Bias. One way for a decision maker to cope with hindsight effects is to use such bias exhibited by observers to his or her advantage. Executives at the Coca-Cola Company did that in 1985. Back then, in an effort to recapture market share from PepsiCo., they decided to drop their original soft drink in favor of a New Coke that had a sweeter, smoother taste. More than two years and $\$ 4$ million spent on research suggested that the New Coke would successfully replace the old formula.

Yet, sales were unsuccessful for the new creation. Brand-loyal and nostalgia-prone soda drinkers filled their basements with remaining cases of the original formula, which they felt was the only authentic Coke. Consumers and analysts alike felt that company executives should have known that removing the original tried and true drink was a mistake. Coke executives responded swiftly to the unfavorable outcome by building upon what it seemed like they should have known. The company brought the original Coke (now labeled "Coke Classic") back on the market after only three months. Virtually every major newspaper featured the return of the "old Coke" on the front page. By the end of that year, Coke Classic was outselling New Coke and Pepsi, thus helping the company to regain and keep the number one position (New Coke, 2005).

The action was so swift, and the reaction to the classic drink so favorable, 
that some observers then had hindsight bias for the second decision to re-release the original drink. They claimed that it was obvious in retrospect that the company action to halt and to re-release the flagship beverage was all part of a marketing ploy to revive interest in that original drink. Coke's president and chief operating officer, Donald Keough, responded to the hindsight bias for both the unfavorable and favorable outcomes. He claimed, "Some critics will say Coca-Cola made a marketing mistake. Some cynics will say that we planned the whole thing. The truth is we are not that dumb, and we are not that smart" (Mikkelson, 1999, p. 6). Hence, the ultimate success of Coke Classic is an example of how a company used observers' hindsight bias and lessons from an unfavorable outcome to its advantage.

Seek the Empathy of Others. Research has shown that asking participants to explain alternative outcomes reduces hindsight bias (e.g., Tomassini \& Grudnitski, 1980). Decision makers dealing with observers' hindsight bias may cope better with the support of those for whom alternative outcomes are readily accessible. Often, individuals sharing the same background or profession as the decision makers are best able to recall the pre-outcome point of view.

For example, hours after pop star Michael Jackson was cleared on ten counts of child molestation in 2005, second-guessing the decision to prosecute was, for some, irresistible. Legal analysts questioned the sensibility of pursuing the case with statements like, "Those just aren't the kinds of cases that prosecutors with good judgment should be bringing" (Broder, 2005, p. 9A). Yet, some fellow prosecutors unconnected with the case were sympathetic. As one said about the district attorney who brought Jackson to trial, "He had an obligation to put his evidence before a jury and let them decide" (Broder, 2005, p. 9A). Such statements by those who understood the foresight situation surrounding the case were supportive of the hindsight-maligned prosecutor.

Focus on Future Perspectives of the Decision-Making Environment. When decisions have unfavorable outcomes, and everyone is saying, "I could have told you your idea would fail," sometimes the best course of action is to believe that the decision and associated outcome will one day be seen in a different light. An example of the value of waiting for future perspectives comes from Paul Schell, who was the mayor of Seattle in 1999. In December of that year, a man suspected of having ties to Canadians with links to Osama bin Laden was caught trying to drive across the Canadian-U.S. border with bomb-making materials. Schell decided to cancel much of Seattle's New Year's Eve festivities (U.S. Takes Last-Minute Terrorist Precautions at Home, Abroad, 1999). He received widespread criticism from constituents who anticipated a special celebratory welcome to the year 2000. In addition, the decision made the city an object of national derision, as Seattle became the subject of jokes on late night network television shows. It was not until 21 
months later, after the 9/11 tragedy in New York City, that others were more convinced about Schell's decision (Feit, Jenniges, Kearney, \& Savage, 2002).

Another way to "wait out negative effects" is to believe that in the long run, even decisions with very unfavorable outcomes can be vindicated. In 1968, African-American student-athletes Tommie Smith and John Carlos placed first and third, respectively, in the 200-meter sprint at the Olympics in Mexico City. At that time, the U.S. and much of the rest of the world struggled with civil rights. While on the victory stand, in an effort to draw attention to these issues, the athletes each raised a fist in a Black-Power salute. The action violated the Olympic ban on expressing political speech during the medal ceremony. Instead of benefiting from the praise often given to victorious athletes, the two were banished from the Olympics and received death threats. As many athletes had backed out of similar plans to protest, Smith and Carlos were undoubtedly told in retrospect that their decision to demonstrate was unwise.

Nonetheless, their actions drew attention to important societal concerns in the United States and, globally, to the issue of an Olympic ban on athletes from nations with apartheid policies. Decades later, many viewed Smith and Carlos's actions at the Olympics not as disgraceful but as courageous. More than 30 years after their protest, they were immortalized in a statue depicting their actions (SJSU Statue is a Fitting Tribute, 2005). Over the years, they have held that they made the right decision. Similarly, decision makers who face unfavorable outcomes can cope with hindsight bias by holding to their convictions that their actions will be viewed positively by others in the future.

Having suggested means for coping with observers' hindsight bias for unfavorable decision outcomes, below are ideas for dealing with the bias for favorable outcomes.

\section{FAVORABLE DECISION OUTCOMES}

Repeat the Success. Observers who show hindsight bias for a decision maker's good fortune can undercut the energy and creativity that the individual put into earning his or her achievement. Most individuals who have worked hard do not want their favorable outcomes attributed to taking foreseeable and easy paths to success. Over 20 years ago, author Jackie Collins decided to write Hollywood Wives, a fictional story about the social scene in the Los Angeles area. After the book became a bestseller, she was frustrated when others claimed that her topic was obvious and simple; they felt that they, too, could have achieved her success. It was harder to undercut her talent, however, when her continued efforts resulted in (to date) 22 New York Times bestsellers (Jackie Collins Biography, n.d.). Repeatedly writing popular novels helped her to prove her skills within her genre, and made it more difficult for others to downplay her achievements.

Use Humor. Another way to cope with hindsight bias for favorable outcomes is with humor. Entertainer Dolly Parton decided to release a song about 
on-again/off-again relationships called, "Here You Come Again." A huge hit, its catchy melody and universal appeal led hindsight-influenced observers to claim that its formula was simple. One went as far to claim that a "monkey" could have attained success with the song, to which the good-natured Parton replied, "A monkey DID!" (E! Entertainment Television, 2005). Humor diffused any tension she may have felt when others belittled her work. Note that, similar to the Coca-Cola executives, she used hindsight bias exhibited by observers to her advantage. She made it into a memorable self-deprecating quote that enhanced her appeal.

React Gracefully. Given the title of this article, perhaps it is appropriate that our final example pertains to the social grace shown by American football player Tom Brady. In five months, Brady went from backup quarterback to winning the 2001 Super Bowl. Not picked for professional football until the sixth round of the National Football League draft, many of his fans claimed that his talent should have been foreseeable. An interviewer asked him if he ever felt the urge to say, "I told you so" (Kroft, 2005, p. 2). Brady responded, "It would be too easy to do. I mean, why be a jerk? ... Let other people say it. It sounds so much better when someone else says it" (Kroft, 2005, p. 2). Brady provides yet another method for dealing well with observers' hindsight bias.

\section{CONCLUSION}

This overview has outlined the effects of hindsight bias in decision-making settings, and has discussed both negative and positive aspects of the bias. Perhaps the mechanisms suggested to reduce negative effects of retrospective thinking-or to cope with it-will be further refined in the research that will continue on the intriguing bias of hindsight distortion.

\section{REFERENCES}

Bauder, D. (2004, March 15). Prince dances into rock and roll hall. Retrieved October 28, 2005 from www.jrp-graphics.com/jb/rarhof.html.

Blank, H., Fischer, V., \& Erdfelder, E. (2003). Hindsight bias in political elections. Memory, 11, 491-504.

Borum, R., Otto, R., \& Golding, S. (1993) Improving clinical judgment and decision making in forensic evaluation. Journal of Psychiatry and Law, 21, 35-76.

Broder, J. M. (2005, June 14). Stinging rebuke for prosecutor. San Jose Mercury News, 9 A.

Bryant, F. B., \& Brockway, J. H. (1997). Hindsight bias in reaction to the verdict in the O. J. Simpson criminal trial. Basic and Applied Social Psychology, 19, 225-241.

Bukszar, E., \& Connolly, T. (1988). Hindsight bias and strategic choice: Some problems in learning from experience. Academy of Management Journal, 31, 628-641.

Burnett, R. (Executive Producer). (2005, September 20). The Late Show with David Letterman. New York: CBS Broadcasting, Incorporated. 
Christensen-Szalanski, J. J. J., \& Willham, C. F. (1991). The hindsight bias: A meta-analysis. Organization Behavior and Human Decision Processes, 48, 147-168.

Connolly, T., \& Bukszar, E. W. (1990). Hindsight bias: Self-flattery or cognitive error? Journal of Behavior Decision Making, 3, 205-211.

E! Entertainment Television (2005). True Hollywood story: Dolly Parton. Los Angeles: E! Networks.

Ellis, J. (2002, March). Life after Enron's death. Fast Company, 118-120.

Feit, J., Jenniges, A., Kearney, P., \& Savage, D. (2002, January 3). Farewell Schell tour. The Stranger. Retrieved October 26, 2005 from www.thestranger. com/seattle/Content?oid=0689.

Fischhoff, B. (1975). Hindsight $\neq$ foresight: The effect of outcome knowledge on judgment under uncertainty, Journal of Experimental Psychology: Human Perception and Performance, 1, 288-299.

Food and Drug Administration Medical Devices Advisory Committee(2000). General and Plastic Surgery Devices Panel Meeting, Gaithersburg, MD.

Fortune Five Hundred Largest U.S. Corporations (2001, April 16). Fortune, p. F1.

Glassman, J. K. (1998, September 27). A simple strategy beats the 'experts'. The Washington Post, p. H01.

Guilbault, R. L., Bryant, F. B., Brockway, J. H., \& Posavac, E. J. (2004). A meta-analysis of research on hindsight bias. Basic and Applied Social Psychology, 26, 103-117.

Hagstrom, R. G. (2004). The Warren Buffet way (2nd edition). Hoboken, NJ: John Wiley \& Sons, Inc.

Hastie, R., Schkade, D., \& Payne, J. W. (1999). Juror judgments in civil cases: Effects of plaintiff's requests and plaintiff's identity on punitive damage awards. Law and Human Behavior, 23, 445-470.

Hawkins, S. A., \& Hastie, R. (1990). Hindsight: Biased judgments of past events after the outcomes are known. Psychological Bulletin, 107, 311-327.

Holzl, E., Kirchler, E., \& Rodler, C. (2002). Hindsight bias in economic expectations: I knew all along what I want to hear. Journal of Applied Psychology, 87, 437-443.

Jackie Collins biography (n.d.). Retrieved October 25, 2005 www.simonsays.com/ content $/$ destination.cfm?sid=33\&pid=341081\&agid $=13$.

Killion, A. (2004, August 28). Balco karma finally catches Jones. San Jose Mercury News, 1D, 5D.

Kinsley, M. (2005, September 13). Hindsight elevates the droves who saw Katrina coming. San Jose Mercury News, 19A.

Krakauer, J. (1997), Into thin air: A personal account of the Mount Everest disaster. New York: Random House, Inc.

Kroft, S. (2005). Tom Brady. CBS News. Retrieved on November 3, 2005 from www.cbsnews.com/stories/2005/11/03/60minutes/ printable1008148.shtml.

Kroll, L., \& Goldman, L. (Eds.). (2005, March 10). Special report: The world's billionaires. Forbes. Retrieved on October 26, 2005 from www.forbes.com/ static/bill2005/LIRC0R3.html?passListId =10\&passYear $=2005 \&$ passList Type $=$ Person\&uniqueId $=$ C0R3\&datatype $=$ Person.

Kula, M. (2004, October 17). Fresh voices: I got breast implants and it backfired, Parade Magazine, 14-15.

Louie, T. A. (1999). Decision makers' hindsight bias after receiving favorable and unfavorable feedback. Journal of Applied Psychology, 84, 29-41.

Louie, T. A. (2005). Hindsight bias and outcome- consistent thoughts when observ- 
ing and making service provider decisions. Organizational Behavior and Human Decision Processes, 98, 88-95.

Louie, T. A., Curren, M. T., \& Harich, K. R. (2000). I knew we would win: Hindsight bias for favorable and unfavorable team decision outcomes. Journal of Applied Psychology, 85, 264-272.

Lowe, J. D., \& Reckers, P. M. J. (1994). The effects of hindsight bias on jurors' evaluations of auditor decisions. Decision Sciences, 25, 401-426.

Mark, M. M., Boburka, R. R., Eyssell, R. M., Cohen, L. L., \& Mellor, S. (2003). I couldn't have seen it coming. Memory, 11, 443-454.

McNulty, S. (2001, November 11). A victim of its opacity. Retrieved on January 23, 2002 from www.ft.com.

Media (n.d.). Retrieved on October 21, 2005, from www.danicaracing.com/media. shtml.

Menec, V. H., \& Weiner, B. (2000). Observers' reactions to genetic testing: The role of hindsight bias and judgments of responsibility. Journal of Applied Social Psychology, 30, 1670-1690.

Mikkelson, B. (1999). Urban legends references pages: Cokelore (Knew Coke). Retrieved on October 24, 2005 from www.snopes.com/cokelore/newcoke.asp

Musch, J. (2003). Personality differences in hindsight bias. Memory, 11, 473-489.

NASA accused of breaking safety rules to launch discovery (2005). Guardian Newspapers. Retrieved on October 20, 2005 from www.buzzle.com/editorials/8-19-2005-75117.asp.

New Coke (2005). Wikipedia. Retrieved on October 24, 2005 from http://en.wikipedia.org/wiki/New_Coke.

Pohl, R. F., Bender, M., \& Lachmann, G. (2002). Hindsight bias around the world. Experimental Psychology, 49, 270-282.

Pohl, R. F., Schwarz, S., Sczesny, S., \& Stahlberg, D. (2003). Hindsight bias in gustatory judgments. Experimental Psychology, 50, 107-115.

Robbennolt, J. K., \& Sobus, M. S. (1997). An integration of hindsight bias and counterfactual thinking: decision making and drug courier profiles. Law and Human Behavior, 21, 539-560.

Schkade, D. A., \& Kilbourne, L. M. (1991). Expectation-outcome consistency and hindsight bias. Organizational Behavior and Human Decision Processes, 49, 105-123.

Shaffer, J., \& Stilley, A. (2005). Patrick, IMS radio network reporter share hometown roots. Retrieved on October 21, 2005 from www.indy500.com/ news/story.php?story_id $=4678$.

Shell, A., \& Krantz, M. (2001, April 16). Buffet vs. Cohen: Which one's right? USA Today, B2.

SISU statue is a fitting tribute (2005, October 18). San Jose Mercury News, 16A.

Sligo, F., \& Stirton, N. (1998). Does hindsight bias change perceptions of business ethics? Journal of Business Ethics, 17, 111-124.

Stewart, J. B. (2003). Getting better all the time. Smart Money, 12, 77-85.

Summary of Sarbanes-Oxley Act of 2002 (2005, October 27). Retrieved from www.aicpa.org/info/sarbanes_oxley_summary.htm.

Surowiecki, J. (2004). The wisdom of crowds. New York: Doubleday.

Taylor, S. E., \& Brown, J. D. (1988). Illusion and well-being: A social psychological perspective on mental health. Psychological Bulletin, 103, 193-210. 
Tomassini, L. A., \& Grudnitski, G. (1990). Coping with hindsight bias in a project. Journal of Systems Management, 31, 22.

U.S. takes last-minute terrorist precautions at home, abroad (1999, December 29). CNN.com. Retrieved on October 26, 2005 from http:/ / archives. cnn.com/1999 /US/12/28/ new.years.wrap.02

Zuckerman, D. (2001). Calling for informed consent on silicone gel implants or an end to sales. Retrieved on August 26, 2002 from www.cpr4womenandfamilies. 
Copyright of Social Cognition is the property of Guilford Publications Inc. and its content may not be copied or emailed to multiple sites or posted to a listserv without the copyright holder's express written permission. However, users may print, download, or email articles for individual use. 